suggested based principally on the degree of abnormality of blood-gas levels, and not on the extent of thoracic bony injuries. A series of 33 cases treated in the Respiratory Emergency Unit of Glasgow Royal Infirmary is presented and briefly discussed. A plea is made for frequent blood-gas analysis in the assessment of treatment of these cases.

We are grateful to Dr. A. C. Forrester and Dr. D. Campbell for their encouragement and criticism during the preparation of this paper. We acknowledge our debt to all members of the hospital staff who have contributed to the care of these patients in the Respiratory Emergency Unit, Glasgow Royal Infirmary.
REFERENCES

Andersen, O. S., Engel, K., Jørgensen, K., and Astrup, P. (1960). Scand. 7. clin. Lab. Invest., 12, 172.

Astrup, P. (1959). In Symposium on $\mathrm{pH}$ and Blood Gas Measuremont, edited by R. F. Woolmer. Churchill, London.

Bull, J. P. (1963). Ann. roy. Coll. Surg. Engl., 33, 175.

Comroe, J. H., Forster, R. E., Dubois, A. B., Briscoe, W. A., and Carlsen, E. (1962). The Lung: Clinical Physiology and Pulmonary Function Tests, 2nd ed., chap. 4. Year Book Medical Publishers, Chicago.

Freeman, J. (1963). Ann. roy. Coll. Surg. Engl., 33, 138.

Griffiths, H, W. C. (1960). F. roy. Coll. Surg. Edinb., 6, 13.

Griffiths, H. W. C. (1960). F. roy. Coll. Surg. Edinb. 6,

Kennedy, A. C., Luke, R. G., Campbell, D., and Cannon, R. N. (1963). Lancet, 2, 1304 .

Maloney, J. V., Schmutzer, K. J., and Raschke, E. (1961). f. thorac. cardiovasc., Surg., 41, 291.

Nahas, G. G. (1963)., Clin. Pharmacol. Ther., 4, 784.

Telford, J., and Keats, A. S. (1961). Anesthesiology, 22, 465

Whitwam, J. G., and Norman, J. (1964). Brit. med. J., 1, 349.

\title{
Diagnosis and Treatment of Erythema Induratum (Bazin)
}

\author{
MICHAEL FEIWEL,* M.B., M.R.C.P. ; DOWLING D. MUNRO, † M.B., M.R.C.P.
}

Brit. med. F., 1965, 1, 1109-1111

Bazin (1861) gave the name of erythema induratum to a nodular eruption which occurred on the lower legs of young women who had tuberculosis. He commented that the condition was not rare. In the next 30 years the disease attracted little notice until, with the discovery of the tubercle bacillus, interest revived and attempts were made, with varying success, to isolate the bacillus from the lesions.

Later, other clinical conditions were described resembling erythema induratum but which were not tuberculous. This, and the declining incidence of tuberculosis generally, may be the reasons why erythema induratum does not now receive sufficient consideration. We wish to draw attention to erythema induratum particularly because of the influx of tuberculosis-prone individuals from overseas. We believe that Bazin's disease is not uncommon in Britain to-day and that it is often misdiagnosed. Even when the diagnosis has been made patients may not receive adequate antituberculous therapy because the physician may not be convinced that he is dealing with a manifestation of active tuberculosis.

Cases.-Table I is a summary of the case histories and investigations in 12 patients with erythema induratum (Bazin). Table II gives their treatment and the clinical response.

\section{Differential Diagnosis}

Disorders of the lower legs characterized by indurated plaques or nodules with or without ulceration present a somewhat complex diagnostic problem. The concept that all were not of the Bazin type was first discussed by Audry (1898), and later by Galloway (1899). However, Whitfield's (1901) name is particularly associated with a form of erythema induratum that is not tuberculous. Montgomery et al. (1944) stated that the following nodular vascular disorders of the legs have many features in common: nodular vasculitis, erythema induratum, erythrocyanosis and pernio, erythema nodosum, panniculitis, recurrent idiopathic thrombophlebitis, and indurated cellulitis secondary to chronic venous stasis. Nodular vasculitis was the term they proposed for the type of case described by Whitfield.

Willkinson (1954) expanded the concept of nodular vasculitis to include a group of disorders with a common vascular basis. In most of these he stressed the aetiological importance of cold

\footnotetext{
- Consultant Dermatologist, St. Mary's Hospital, Paddington General Hospital, North Middlesex Hospital, and 'St. Charles' Hospital, London. † Senior Registrar, Dermatology Department, St. Mary's Hospital,
}

and peripheral venous stasis. He remarked on the additional effect of tuberculosis in some cases, and stated that "The question resolves itself into what part, if any, the tuberculous process plays in a given lesion, even if the disease is active in the patient. One cannot afford to be too sceptical."

As a result of the present study we believe that the role of tuberculosis should be emphasized, and that a case of erythema induratum should be considered to be of tuberculous origin unless reasons for excluding this are particularly strong. Telford's (1937) view that erythema induratum is the same condition as erythrocyanosis and is never tuberculous cannot be accepted. Nor do we agree with Sandberg and Adams (1962), who regard erythema induratum merely as a descriptive term that does not denote a specific tuberculous aetiology.

In our cases wrong diagnoses were prominent and as a result several patients had prolonged disability. Emphasis that Bazin's disease occurs in young women whereas nodular vasculitis is seen in the middle-aged may account for the diagnosis of nodular vasculitis made in some of our patients without sufficient investigation. Two-thirds of our patients were over the age of 35 , and it is important to realize that erythema induratum is not confined to younger age groups but may occur later, even in the sixties. One patient of Montgomery et al. (1944), a woman aged 54-diagnosed as having nodular vasculitis because clinical, pathological, and bacteriological investigation had failed to disclose any evidence of tuberculosis-developed a tuberculous cervical adenitis within six months, and then showed a strongly positive tuberculin reaction. In addition to nodular vasculitis other diagnoses had included thrombophlebitis migrans, perniosis, erythema nodosum, and collagen disease, and the patients had failed to respond to treatment. Those previously recognized as having Bazin's disease had received insufficient or inadequate antituberculous therapy and had relapsed.

\section{Clinical Features}

Most patients showed typical clinical features of erythema induratum. Frequently they presented with crops of small, tender, and painful erythematous or dusky nodules of $1 \mathrm{~cm}$. diameter or less occurring on the lower legs. Some of these nodules ulcerated, often with aggravation of pain. The influence of cold and peripheral vascular stasis could be observed in half of those patients who were worse in winter and in whom nodules tended to occur particularly in the calves and back of the ankles. Females outnumbered men by 11 to 1 . 


\section{Relationship to Tuberculosis}

Two-thirds of our patients had a personal or family history of tuberculosis or gave radiological evidence of having had the disease. None had clinical or radiological evidence of active pulmonary tuberculosis or of tuberculous adenitis. Three patients were West Indian, the one male was a Pakistani. Biopsy of a lesion was performed in seven patients. In only one was a characteristic tuberculoid granuloma found. The other biopsies showed perivascular cuffing with round cells and some vessel-intimal proliferation and a surrounding non-specific chronic granuloma without Langhans giant cells or caseation. Tubercle bacilli were not seen. The total white blood count was normal in all cases, and only one showed a consistent mild lymphocytosis. The erythrocyte sedimentation rate was high in many cases but in one-third it was normal. Every patient had a high sensitivity to old tuberculin, the Mantoux test being strongly positive at a dilution of $1: 10,000$ in 10 and positive in two. The high degree of sensitivity remained after antituberculous therapy, though the reaction was less marked. Another constant finding in our patients whose plasma protein was estimated prior to treatment was the rise in globulins, particularly in gamma-globulins.

The tuberculous aetiology in our patients was regarded as established by the finding that erythema induratum was associated in many with a past history of tuberculosis and in all with a high tuberculin sensitivity. Stegmaier (1959) is among the few who have commented on the high degree of sensitivity to old tuberculin in erythema induratum. In accordance with reports in the literature we did not think it necessary to confirm the diagnosis by obtaining a characteristic tuberculoid histology, by demonstrating the bacillus, or by a positive guinea-pig inoculation from excised tissue. Such findings are rare in erythema induratum. A normal E.S.R., as found in some of our patients, might deter the physician from making a diagnosis of tuberculosis. Again, the presence of increased gamma-globulins, a raised E.S.R., and a histological finding of vasculitis might suggest a collagen disorder. The uniform response to adequate antituberculous therapy, however, has justified the diagnosis of erythema induratum (Bazin) in our cases, though no focus of active tuberculosis responsible for the lesions was found in any of them.

\section{Treatment}

The patients were treated with streptomycin, para-aminosalicylic acid, and isoniazid. At least two of these drugs were administered, usually para-aminosalicylic acid $12.5 \mathrm{~g}$. and isoniazid 200-260 mg. daily. We believe that adequate antituberculous therapy should be given for at least nine months. In patients who tend to default from oral treatment, injections of streptomycin $1 \mathrm{~g}$. daily have their place. The clinical results as outlined in Table II were good except in those patients who did not fully adhere to their course of treatment. A feature of the response was the improvement in general health and increase in weight even in patients who had not complained of systemic symptoms before beginning treatment. In view of the previous chronicity shown by some of the patients a longer period of follow-up is required for final evaluation of results.

TABLE I.-Clinical and Investigative Findings in 12 Patients with Erythema Induratum (Bazin)

\begin{tabular}{|c|c|c|c|c|c|c|c|c|c|c|c|c|}
\hline \multirow{3}{*}{$\begin{array}{c}\text { Case } \\
\text { No. } \\
1\end{array}$} & \multirow{2}{*}{\multicolumn{2}{|c|}{$\begin{array}{l}\text { Age } \\
\text { and } \\
\text { Sex }\end{array}$}} & \multirow{2}{*}{$\begin{array}{c}\text { Duration } \\
\text { of } \\
\text { Symptoms }\end{array}$} & \multirow{2}{*}{ Ulceration } & \multirow{2}{*}{$\begin{array}{l}\text { Worse } \\
\text { in } \\
\text { Cold }\end{array}$} & \multirow{2}{*}{$\begin{array}{c}\text { Family } \\
\text { History of } \\
\text { Tuberculosis }\end{array}$} & \multirow{2}{*}{$\begin{array}{c}\text { Evidence } \\
\text { of Previous } \\
\text { Tuberculosis }\end{array}$} & \multirow{2}{*}{$\begin{array}{l}\text { Maximum } \\
\text { Blood } \\
\text { Sedimentation } \\
\text { Rate in } \mathrm{mm} . / \mathrm{hr} . \\
\text { (Westergen) }\end{array}$} & \multicolumn{2}{|c|}{$\begin{array}{c}\text { Reaction to Old } \\
\text { Tuberculin } 1 \text { in } 10,000\end{array}$} & \multirow{2}{*}{$\begin{array}{l}\text { Plasma } \\
\text { Globulins } \\
\text { Prior to } \\
\text { Therapy }\end{array}$} & \multirow{2}{*}{$\begin{array}{c}\text { Histology of Skin } \\
\text { Nodule }\end{array}$} \\
\hline & & & & & & & & & $\begin{array}{l}\text { Before } \\
\text { Therapy }\end{array}$ & $\begin{array}{l}\text { After } \\
\text { Therapy }\end{array}$ & & \\
\hline & 57 & $\mathbf{F}$ & 6 years & + & + & & Healed apical focus & 22 & ++ & + & Raised gamma & $\begin{array}{l}\text { Tuberculoid granu- } \\
\text { loma of dermis and } \\
\text { hypodermis }\end{array}$ \\
\hline 2 & 53 & $\mathbf{F}$ & $26 "$ & & & & $\begin{array}{l}\text { Cervical adenitis. } \\
\text { Hilar glands calcified }\end{array}$ & 42 & ++ & + & Raised gamma & \\
\hline $\begin{array}{l}3 \\
4\end{array}$ & $\begin{array}{l}52 \\
51\end{array}$ & $\underset{\mathbf{F}}{\mathbf{F}}$ & 6 months & + & $\begin{array}{l}+ \\
+\end{array}$ & + & $\begin{array}{l}\text { Tenosynovitis } \\
\text { Hilar gland and pul- } \\
\text { monary calcification }\end{array}$ & $\begin{array}{r}9 \\
12\end{array}$ & $\begin{array}{l}++ \\
++\end{array}$ & + & $\begin{array}{l}\text { Raised gamma } \\
\text { Raised gamma }\end{array}$ & \\
\hline 5 & 45 & $\mathbf{F}$ & 3 & & + & & $\begin{array}{l}\text { Hilar gland and pul- } \\
\text { monary calcification. } \\
\text { Peritonitis }\end{array}$ & 40 & +++ & +++ & Raised gamma & Chronic granuloma \\
\hline 6 & 37 & $\mathbf{F}$ & 18, & + & + & + & $\begin{array}{l}\text { Pervical adenitis. } \\
\text { Pleurisy with effu- } \\
\text { sion. Pulmonary } \\
\text { calcification. }\end{array}$ & 11 & + & + & & $\begin{array}{l}\text { Chronic granuloma } \\
\text { with perivascular } \\
\text { cuffing. }\end{array}$ \\
\hline 7 & 36 & $\mathbf{F}$ & $9 "$ & + & & & $\begin{array}{l}\text { Pulmonary calcifica- } \\
\text { tion }\end{array}$ & 27 & + & + & $\begin{array}{l}\text { (Normal fol- } \\
\text { lowing } \\
\text { therapy) }\end{array}$ & \\
\hline 8 & 33 & $\mathrm{~F}$ & 5 " & + & + & & & 68 & ++ & + & $\begin{array}{l}\text { (Normal } \\
\text { following } \\
\text { therapy) }\end{array}$ & $\begin{array}{l}\text { Vasculitis with inti- } \\
\text { mal proliferation }\end{array}$ \\
\hline $\begin{array}{r}9 \\
10 \\
11\end{array}$ & $\begin{array}{l}28 \\
27 \\
25\end{array}$ & $\begin{array}{l}\mathrm{F} \\
\mathrm{F}\end{array}$ & $\begin{array}{l}3 \text { ", } \\
18 \text { month }\end{array}$ & + & + & + & & $\begin{array}{l}45 \\
65 \\
35\end{array}$ & $\begin{array}{l}++ \\
++ \\
++\end{array}$ & $\stackrel{+}{+}+$ & $\begin{array}{l}\text { Raised gamma } \\
\text { Raised gamma } \\
\text { Raised gamma }\end{array}$ & $\begin{array}{l}\text { Chronic granuloma } \\
\text { Chronic granuloma } \\
\text { with perivascular } \\
\text { cuffing }\end{array}$ \\
\hline 12 & 31 & M & 12 years & + & & & & 10 & ++ & + & Raised alpha 2 & Chronic granuloma \\
\hline
\end{tabular}

TABLE II.-Treatment and Clinical Response

\begin{tabular}{|c|c|c|c|c|c|c|c|c|c|}
\hline \multirow{2}{*}{$\begin{array}{r}\text { Case } \\
\text { No. } \\
\frac{1}{2}\end{array}$} & \multirow{2}{*}{\begin{tabular}{|l}
$\begin{array}{c}\text { Duration and Type of Treatment } \\
\text { at Time of Latest Follow-up }\end{array}$ \\
$\begin{array}{l}\text { P.A.S., isoniazid } 8 \text { months } \\
\text { P.A.S., isoniazid } 4 \text { months } \\
\text { (intermittent therapy) }\end{array}$
\end{tabular}} & \multirow{2}{*}{$\begin{array}{l}\text { Time from Onset of } \\
\text { Therapy Before } \\
\text { Symptoms Improved }\end{array}$} & \multirow{2}{*}{$\begin{array}{l}\text { Latest Appearance of } \\
\text { New Lesions After } \\
\text { Onset of Therapy }\end{array}$} & \multicolumn{2}{|c|}{$\begin{array}{c}\text { Change in General } \\
\text { State of Health }\end{array}$} & \multicolumn{2}{|c|}{$\begin{array}{l}\text { Condition When } \\
\text { Last Examined }\end{array}$} & \multicolumn{2}{|c|}{$\begin{array}{l}\text { Length of Follow-up } \\
\text { from Onset of } \\
\text { Treatment }\end{array}$} \\
\hline & & & & $\begin{array}{l}\text { Weight inc } \\
\text { Nil }\end{array}$ & & $\begin{array}{l}\text { No nodules. } \\
\text { No nodules }\end{array}$ & Scars & $\begin{array}{l}8 \mathrm{mo} \\
13\end{array}$ & $\begin{array}{l}\text { nths } \\
\text { " }\end{array}$ \\
\hline $\begin{array}{l}3 \\
4 \\
5\end{array}$ & $\begin{array}{l}\text { P.A.S., isoniazid } 11 \text { months } \\
\text { P.A.S., isoniazid } 10 \text { months } \\
\text { P.A.S., isoniazid } 7 \text { months }\end{array}$ & $\begin{array}{l}6 \text { weeks } \\
8 \text { weeks } \\
\text { Under } 4 \text { weeks }\end{array}$ & $\begin{array}{l}4 \text { months } \\
\text { None } \\
\text { None }\end{array}$ & $\begin{array}{l}\text { Nil } \\
\text { Nil } \\
\text { Improved. }\end{array}$ & & $\begin{array}{l}\text { No nodules. } \\
\text { No nodules } \\
\text { No nodules }\end{array}$ & Scars & $\begin{array}{r}11 \\
10 \\
7\end{array}$ & ", \\
\hline 6 & $\begin{array}{l}\text { Streptomycin. } 6 \text { months. } \\
\text { P.A.S., isoniazid 1 year } \\
\text { (intermittent therapy) }\end{array}$ & Under 4 weeks & $\begin{array}{l}\text { No nodules when on } \\
\text { streptomycin. Inter- } \\
\text { mittent oral therapy }\end{array}$ & Nil eight it & & $\begin{array}{l}\text { Still gets nodu } \\
\text { cold weather } \\
\text { Scars. }\end{array}$ & ules in & $2 y$ & ears \\
\hline $\begin{array}{l}7 \\
8\end{array}$ & $\begin{array}{l}\text { P.A.S., isoniazid } 9 \text { months } \\
\text { P.A.S., isoniazid } 13 \text { months }\end{array}$ & $\begin{array}{l}\text { Under } 4 \text { weeks } \\
6 \text { weeks }\end{array}$ & $\begin{array}{l}\text { with relapses } \\
\text { None } \\
\text { None }\end{array}$ & $\begin{array}{l}\text { Nil } \\
\text { Improved. } \\
\text { increase }\end{array}$ & Weight & $\begin{array}{l}\text { No nodules. } \\
\text { Scars }\end{array}$ & Scars & ${ }_{15}^{9} \mathrm{~m}$ & onths \\
\hline 9 & Streptomycin 8 days. & 6 " & 6 weeks & Improved. & Weight & No nodules & & 9 & ", \\
\hline 10 & $\begin{array}{l}\text { P.A.S., isoniazid } 9 \text { months } \\
\text { Streptomycin } 3 \text { weeks } \\
\text { P.A.S. isoniazid } 12 \text { months }\end{array}$ & $4 \quad$ & None & $\begin{array}{l}\text { increase } \\
\text { Improved. } \\
\text { increase }\end{array}$ & Weight & No nodules. & Scars & 15 & ", \\
\hline $\begin{array}{l}11 \\
12\end{array}$ & $\begin{array}{l}\text { P.A.S., isoniazid } 7 \text { months } \\
\text { Streptomycin } 3 \text { months. } \\
\text { P.A.S., isoniazid } 9 \text { months }\end{array}$ & $\begin{array}{l}4 \text { weeks } \\
6 " \Rightarrow\end{array}$ & $\begin{array}{l}\text { None } \\
\text { None }\end{array}$ & $\begin{array}{l}\text { Improved } \\
\text { Improved. } \\
\text { increase }\end{array}$ & Weight & $\begin{array}{l}\text { No nodules } \\
\text { No nodules. }\end{array}$ & Scars & $\begin{array}{l}7 \\
9\end{array}$ & $"$ \\
\hline
\end{tabular}


Apart from simple dressings to ulcerated lesions, no treatment, such as supportive bandages, was used while the antituberculous therapy was given.

\section{Summary}

Twelve cases of nodular or ulcerative eruptions on the lower legs which showed evidence of tuberculosis are described. Reasons for misdiagnosis are discussed. The occurrence of erythema induratum (Bazin) in Britain and the incidence in older patients are emphasized.
REFERENCES

Audry, C. (1898). Ann. Derm. Syph. (Paris), p. 209.

Bazin, A. P. E. (1861). Leçons théoriques et cliniques sur la scrofule, 2nd ed., p. 146. Delahaye, Paris.

Galloway, J. (1899). Brit. F. Derm., 11, 206.

Montgomery, H., O'Leary, P. A., and Barker, N. W. (1944). Coll. Pap. Mayo Clin., 36, 461 .

Sandberg, D. H., and Adams, J. M. (1962). f. Pediat., 61, 880.

Stegmaier, O. (1959). Arch. Derm., 80, 611.

Telford, E. D. (1937). Ibid., 36, 952.

Whitfield, A. (1901). Amer. F. med. Sci., 122, 828.

Wilkinson, D. S. (1954). Brit. F. Derm., 66, 201.

\title{
Complication Following Fracture-dislocation of Hip
}

\author{
D. W. M. HAW,* M.B., CH.B., B.SC., F.R.C.S.
}

Brit. med. F., 1965, 1, 1111-1112

I would like to report an unusual case of hazard to the sciatic nerve.

A youth aged 17 was riding a motor-cycle when he collided with a car and sustained an injury to his right hip.

On admission to hospital his general condition was good, pulse 80 , blood-pressure $140 / 80$. He had adduction medial rotation and shortening of the right thigh, with all movements of the hip limited by pain and spasm, and an abrasion over the right patella. There was no motor or sensory loss in the leg and the circulation was not impaired. Radiographs showed a posterior fracture-dislocation of the right hip with a large posterior fragment of acetabulum (see Fig. 1).

It was decided to perform an open operation and fix the large posterior fragment with a screw. Closed reduction was done first, with flexion of the hip to right angles, traction, and internal rotation. This was accomplished easily at the first attempt. A subsequent radiograph showed a satisfactory reduction.

* Senior Orthopaedic Registrar, Hull Royal Infirmary.

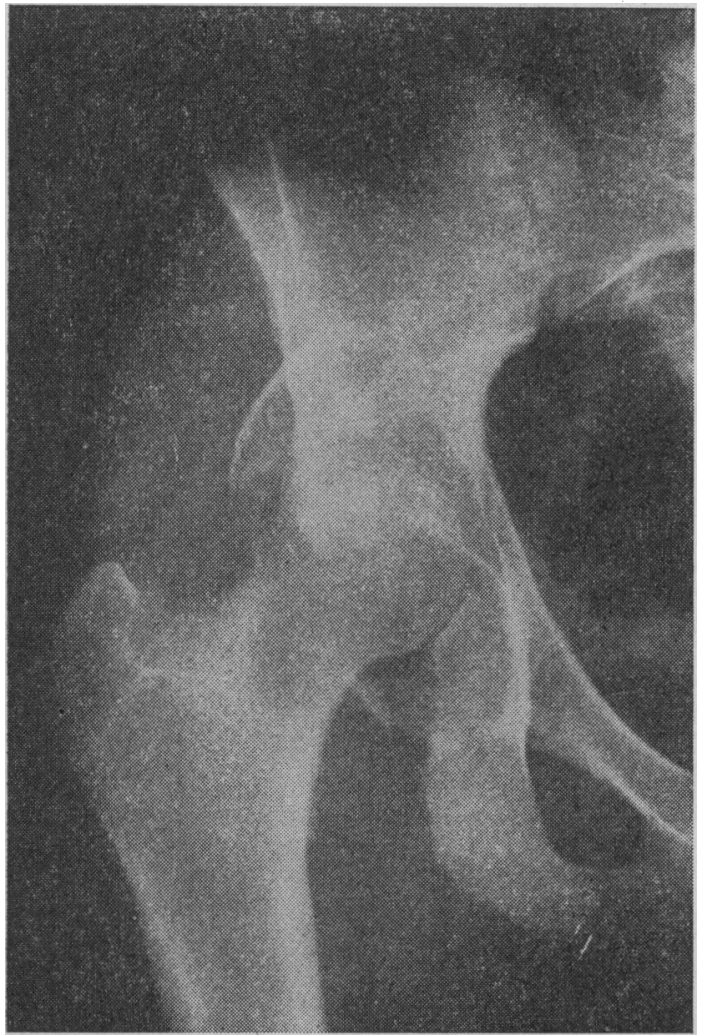

FIG. 1.-Radiograph showing a posterior fracture-dislocation of the hip with a large acetabular fragment.
At operation the hip was approached posteriorly with an inverted L-shaped incision. The fibres of gluteus maximus were split, the incision then being continued vertically into the fascia lata. This procedure exposed the external rotators of the hip. The obturator internus and two gemelli were divided and retracted to give a better exposure. The capsule was torn posteriorly, which revealed the large posterior fragment in good position, but after reduction the sciatic nerve had been trapped between fragments $A$ and $B$ (Fig. 2a). The fracture had passed horizontally through the ischial spine, and at the time of dislocation fragment $A$ had rotated, allowing the sciatic nerve to slip between the fragments. The sciatic nerve was mobilized, and tapes were passed round the nerve, which was coaxed round the spur of fragment $A$. Fragment $A$ was reduced as accurately as possible with a bone hook and fixed to B with a 1-in. $(2.5-\mathrm{cm}$.) vitallium screw (see Fig. $2 \mathrm{~b}$ ), A small slip of pyriformis was sutured under the nerve to protect it from the fracture site. Loss of blood at the operation was less than half a pint. Two pints $(1,140 \mathrm{ml}$.) of blood was replaced.

The patient made an uneventful recovery. On the day after operation there was no evidence of motor or sensory loss in the sciatic nerve. He was immobilized on Hamilton Russell traction for six weeks. Active hip movements were begun one month after the operation. He remained free in bed one week after the traction had been discontinued and was then allowed to walk with crutches. No weight was taken on the affected limb.

He was seen three and a half months after operation. He walked with a slight limp; the Trendelenburg test was negative; flexion of the hip was limited by 15 degrees. A radiograph taken at this time showed that the fracture had united without displacement ; the femoral head showed a normal density and the joint space was somewhat narrowed.

\section{Discussion}

Armstrong (1948), in a review of 101 cases of traumatic dislocation of the hip, recorded seven cases associated with sciatic palsy. In six of these cases a fragment of bone was displaced into the region of the sciatic notch. The only patient who recovered completely was operated on five days after the injury. Two others operated on after a fivemonth interval only partially recovered. The remaining four showed no recovery.

Watson-Jones (1953) emFIG. 2. - Diagram, a posterior view, (a) showing the
sciatic nerve trapped between fragments $A$ and $B$. (b) Fragments $A$ and $B$ fixed with a vitallium screw. 